\title{
Mouse model of anti-NMDA receptor post-herpes simplex encephalitis
}

Jenny Linnoila, MD, PhD,* Benjamin Pulli, MD,* Thaís Armangué, MD, PhD, Jesús Planagumà, PhD, Radha Narsimhan, PhD, Stefan Schob, MD, Matthias W.G. Zeller, MD, Josep Dalmau, MD, PhD,* and John Chen, MD, PhD*

Neurol Neuroimmunol Neuroinflamm 2019;6:e529. doi:10.1212/NXI.0000000000000529
Correspondence

Dr. Linnoila

linnoila.jenny@mgh.harvard.edu

\begin{abstract}
Objective

To develop an endogenous rodent model of postinfectious anti-NMDA receptor (NMDAR) encephalitis.
\end{abstract}

\section{Methods}

Six mice were inoculated intranasally with herpes simplex virus (HSV) 1 and subsequently treated with acyclovir for 2 weeks. Serum was collected at 3, 6, and 8 weeks postinoculation and tested for NMDAR antibodies through a cell-based assay. Eight weeks postinoculation, mice were killed and their brains were sectioned and immunostained with antibodies to postsynaptic density (PSD)-95 and NMDARs. Colocalization of hippocampal PSD-95 and NMDAR clusters, representing postsynaptic membrane NMDARs, was quantified via confocal imaging. Hippocampi were additionally analyzed for NMDAR and PSD-95 protein using Western blot analysis.

\section{Results}

Four of 6 mice (67\%) developed serum antibodies to NMDARs: 1 at 3 weeks, 1 at 6 weeks, and 2 at 8 weeks postinoculation. As compared to inoculated mice that did not develop NMDAR antibodies, immunofluorescence staining revealed decreased hippocampal postsynaptic membrane NMDARs in mice with serum antibodies at 8 weeks postinoculation. Western blot analysis showed that mice that had NMDAR antibodies at 8 weeks had decreased total NMDAR but not PSD-95 protein in hippocampal extracts $(p<0.05)$.

\section{Conclusions}

Mice inoculated intranasally with HSV-1 developed serum NMDAR antibodies. These antibodies were associated with reduced hippocampal NMDARs, as has been shown in previous models where antibodies from patients with anti-NMDAR encephalitis were infused into mice, paving the way for future studies into the pathophysiology of autoimmune encephalitides. 


\section{Glossary}

ACV = acyclovir; HSE = HSV encephalitis; HSV = herpes simplex virus; IgG = immunoglobulin G; NMDAR = NMDA receptor; PSD = postsynaptic density.

Herpes simplex virus (HSV)-1 is neurotropic ${ }^{1}$ and highly destructive when it infects the brain. Despite treatment, HSV encephalitis (HSE) has a mortality of $10 \%-30 \%$. Many patients with HSE are left with devastating sequelae, including short-term memory deficits, behavioral changes, and seizures. It was long thought that HSE recurs in a subset of patients despite treatment and known that some children develop post-HSE choreoathetosis. ${ }^{2}$ However, repeat CSF analysis in these patients was negative for HSV. Surprisingly, retrospective analyses ${ }^{3,4}$ detected NMDA receptor (NMDAR) antibodies in patients' sera and/or CSF, suggesting that the new neurologic symptoms actually represented autoimmune encephalitis. A subsequent prospective study has shown that $27 \%$ of patients with HSE develop autoimmune encephalitis, often associated with NMDAR antibodies. ${ }^{5}$

Based on these observations, the current study was undertaken to develop an endogenous rodent model of postHSE NMDAR encephalitis to allow for detailed studies into the pathogenesis of autoimmune encephalitides. In the model described below, mice were infected with HSV-1 and subsequently treated with acyclovir (ACV), mirroring the clinical course of patients with HSE.

\section{Methods}

Please refer to the online supplemental methods (e-methods, links.lww.com/NXI/A92) for detailed descriptions of procedural details.

\section{Standard protocol approvals}

All animal procedures were approved by our Institutional Animal Care and Use Committee. Collection and banking of CSF from patients with autoimmune encephalitis was approved by our institutional review board.

\section{Inoculation with HSV-1 and treatment with ACV}

Six female BALB $/ \mathrm{c}$ mice were intranasally inoculated with 0.5 (mouse 2) or $1 \times 10^{6}$ (mice 1 and 3-6) plaque-forming units of HSV-1 (strain 17 syn $\left.^{+}\right)^{6}$ and treated with ACV (AuroMedics, $20 \mathrm{mg} / \mathrm{kg} /$ dose twice daily) via intraperitoneal injections for 2 weeks. Two age- and sex-matched control mice were inoculated with vehicle solution.

\section{Serum collection and immunofluorescent cell-based assay for NMDAR Ab detection}

Retro-orbital bleeds were performed preinoculation and at 3, 6 , and 8 weeks post-HSV inoculation, and the presence of NMDAR antibodies in mouse sera was determined using a GluN1-NMDAR-transfected HEK293 cell-based assay as previously reported. ${ }^{7}$

\section{Immunofluorescence and confocal microscopy}

At 8 weeks, mice were killed, brains were harvested, and $7-\mu \mathrm{m}$ thick sections were stained for NMDARs and postsynaptic density (PSD)-95, similarly to previously described. ${ }^{8}$ Spot detection and three-dimensional colocalization of NMDARs and PSD-95 were performed to quantify postsynaptic membrane NMDAR clusters.

\section{Immunoblot analyses}

Hippocampi were dissected and homogenized from thawed brain halves, nuclei were removed, and $10 \mu \mathrm{g}$ protein (confirmed by bicinchoninic acid assay) of each sample was immunoblotted for NMDARs, PSD-95, and actin, similarly to previously described. ${ }^{8}$

\section{Statistics}

Results are expressed as mean with standard error of the mean error bars. NMDAR and PSD-95 colocalized spots, as well as hippocampal NMDAR and PSD-95 protein normalized to actin (loading control), were compared with one-way analysis of variance (ANOVA). Further pooled (NMDAR antibodynegative vs positive samples) were also compared with a MannWhitney $U$ test. $p<0.05$ was considered statistically significant.

\section{Data availability}

Data will be shared upon request from any qualified investigator.

\section{Results}

\section{Mice inoculated intranasally with HSV-1 develop antibodies to NMDARs}

Four of 6 mice $(67 \%)$ inoculated intranasally with HSV-1 developed NMDAR antibodies in their sera, as demonstrated by a GluN1-transfected HEK293 cell-based assay (figure 1, A, B): HSE mouse 4 transiently at 3 weeks, HSE mouse 3 transiently at 6 weeks, and HSE mice 5 and 6 at 8 weeks postinoculation. No mice had NMDAR antibodies preinoculation, and serum antibodies were not detected in HSE mice 1 and 2 at any time point. HSE mouse 6 had immunoglobulin $\mathrm{G}(\mathrm{IgG})$ to an unknown antigen at 6 weeks (figure 1 , $\mathrm{B}$, arrows) and developed additional IgG to NMDARs at 8 weeks (figure 1, A, B).

\section{Mice with antibodies to NMDARs have decreased hippocampal postsynaptic membrane NMDARs}

Immunostaining for NMDARs (figure 2A) and colocalization with PSD-95 (figure 2C) revealed a decrease in hippocampal postsynaptic membrane NMDAR clusters in HSE mice 4-6 
Figure 1 Mice inoculated intranasally with HSV-1 develop antibodies to NMDARs

\begin{tabular}{|c|c|c|c|c|}
\hline \multirow{2}{*}{ HSE mouse } & \multirow{2}{*}{ Preinoculation } & \multicolumn{3}{|c|}{ Week } \\
\cline { 3 - 5 } & & 3 & 6 & 8 \\
\hline 1 & - & - & - & - \\
\hline 2 & - & - & - & - \\
\hline 3 & - & - & + & - \\
\hline 4 & - & + & - & + \\
\hline 5 & - & - & - & $\#+$ \\
\hline 6 & - & - & $\#$ & - \\
\hline
\end{tabular}
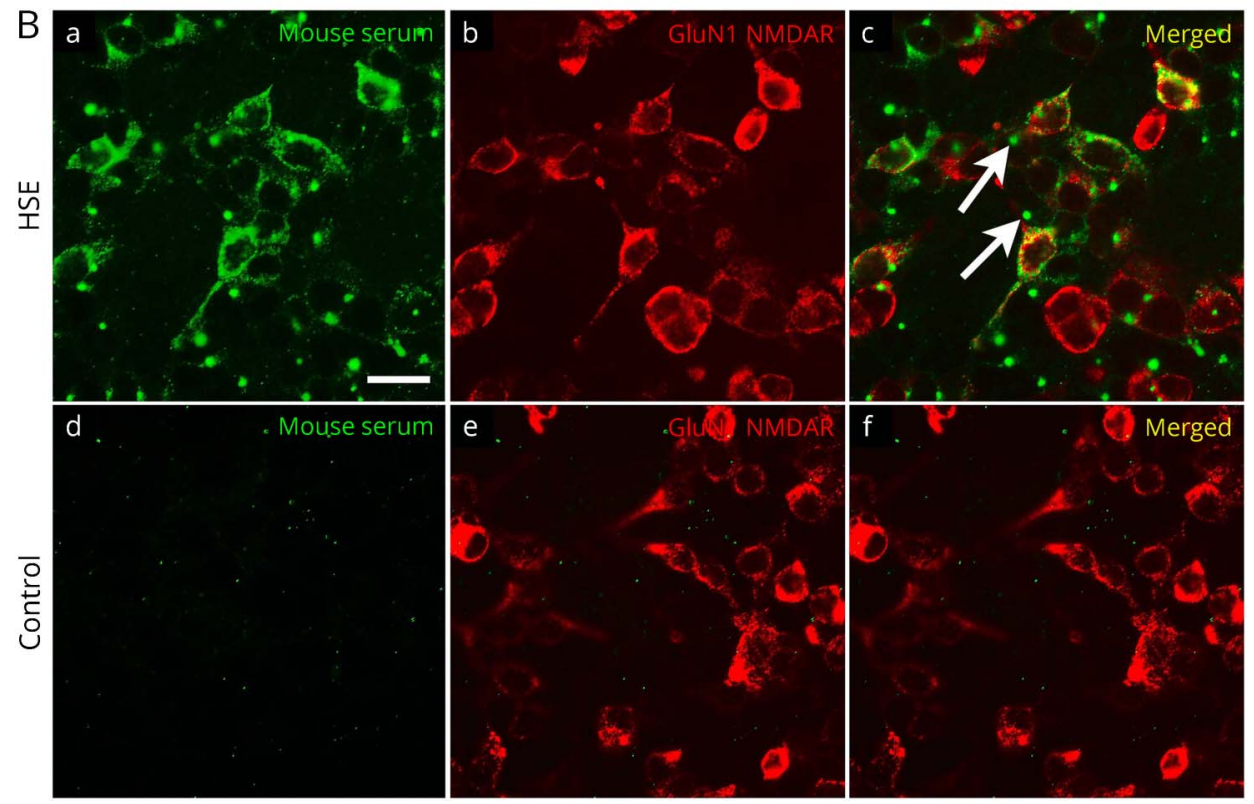

(A) NMDAR (GluN1 subunit)-expressing HEK293 cells incubated with mouse serum and probed with anti-mouse immunoglobulin $\mathrm{G}$ to evaluate for serum NMDAR antibodies (Abs) in HSE mice preinoculation and at 3,6 , and 8 weeks postinoculation with HSV-1. +: NMDAR Abs in serum; -: no NMDAR Abs in serum; \#: antibody to unknown antigen in serum. (B) Representative images of GluN1-NMDAR-transfected HEK293 cell-based assay incubated with 8-week sample from HSE mouse 6 serum $(a-c)$ or control serum (d-f) probed with anti-mouse immunoglobulin G (IgG; a, d) or commercial anti-NMDAR (GluN1) probed with antirabbit IgG ( $b$ and e). Merged images ( $c$ and $f$ ) show that whereas HSE mouse 6 developed serum antibodies that bind to NMDARs (as evident by colocalization with the commercial NMDAR $A b, c$, yellow cell surface labeling), no NMDAR Abs are seen in control serum (f). Note the additional IgG Ab toward an unknown target (a, c; green dots, two of which are highlighted by arrows). Scale bar $(a)=10 \mu \mathrm{m}$.

compared with control mice and HSE mice 1-3. A significant difference was found between HSE mice 1 and 2 and HSE mice 5 and $6(231 \pm 23$ vs $117 \pm 12$, respectively, $p=0.03)$ (figure 2B.a), as well as a trend toward a decrease between control mice and HSE mice 5 and $6(204 \pm 4$ vs $117 \pm 12$, respectively, $p=0.07)$. When data were pooled based on serum NMDAR antibody status (control mice and HSE mice 1 and 2 vs HSE mice 3-6, figure 2B.b), a trend toward decreased hippocampal postsynaptic membrane NMDAR clusters was found $(217 \pm 12$ vs $155 \pm 25, p=0.20)$.

\section{Mice with antibodies to NMDARs have decreased hippocampal NMDAR protein}

Immunoblot analysis (figure $3 \mathrm{~A}$ ) revealed that HSE mice 5 and 6 had a significant decrease in total extranuclear hippocampal NMDAR but not PSD-95 protein compared with control mice and HSE mice 1 and 2 (figure 3B) (63.2 \pm 9.3 vs $100.0 \pm 8.3, p=0.0498$, and $101.3 \pm 2.7, p=0.045$, respectively, normalized to mean of control as $100 \%)$. When data were pooled based on serum NMDAR antibody status (control mice and HSE mice 1 and 2 vs HSE mice 3-6), a similar decrease was found for hippocampal NMDAR $(100.6 \pm 3.6$ vs $68.9 \pm 5.0, p=0.029)$ but not PSD-95 protein levels (figure 3C).

\section{Discussion}

In this mouse model of anti-NMDAR post-HSE encephalitis, we showed that two-thirds of mice inoculated intranasally with HSV-1 and treated with ACV developed serum NMDAR antibodies using the same cell-based assay that is used to detect NMDAR antibodies in human samples. One mouse (no. 6) developed antibodies to an unknown target in addition to NMDAR antibodies, further mirroring what has been reported in some patients after HSE., ${ }^{5,9}$ Although NMDAR antibodies were not directly demonstrated to be binding to the mouse hippocampi in these studies, a decreased number of hippocampal postsynaptic NMDAR clusters and decreased hippocampal NMDAR protein were found in mice that had serum NMDAR antibodies at the time of sacrifice. The decrease in hippocampal NMDARs suggests that these mouse antibodies are similar to patient-derived NMDAR antibodies. ${ }^{8}$ Effects on hippocampal NMDARs were less pronounced for mice that transiently developed NMDAR antibodies, suggesting that their effects may have been short lived.

The previously published animal model of NMDAR encephalitis ${ }^{8,10}$ relies on adoptive transfer, infusing human NMDAR antibodies into mouse brains. Mice in that model have 


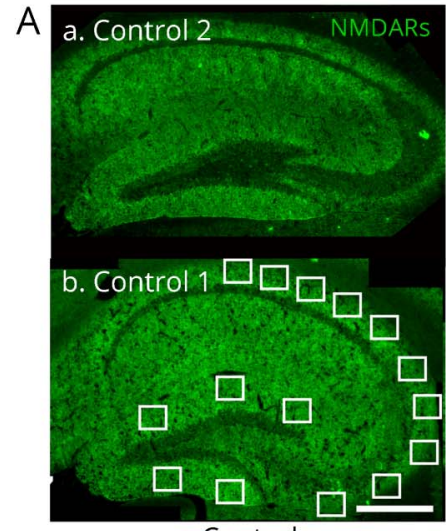

Control

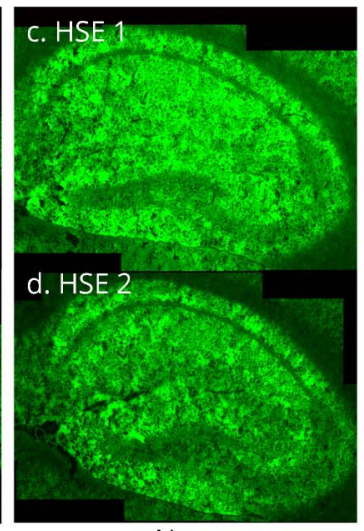

None

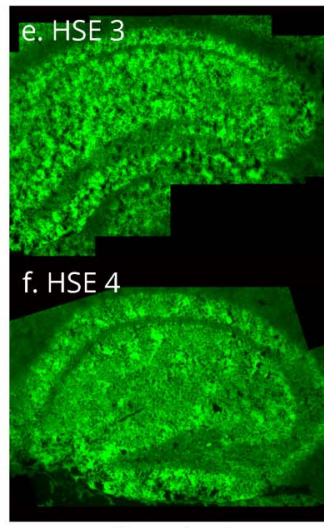

Transient

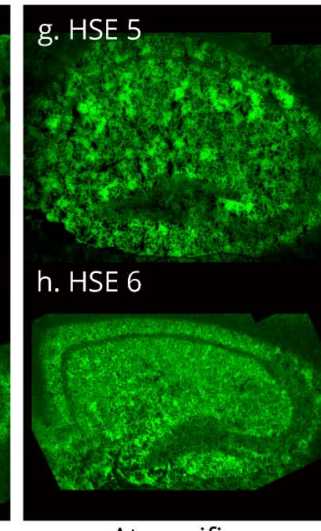

At sacrifice

NMDAR Abs
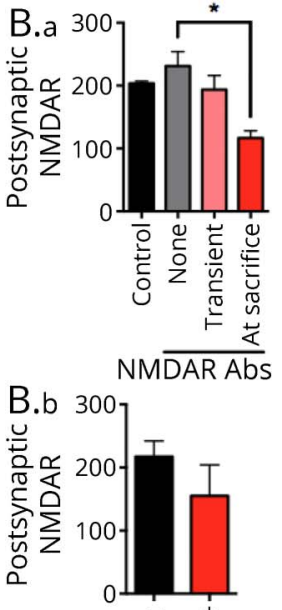

NMDAR Abs
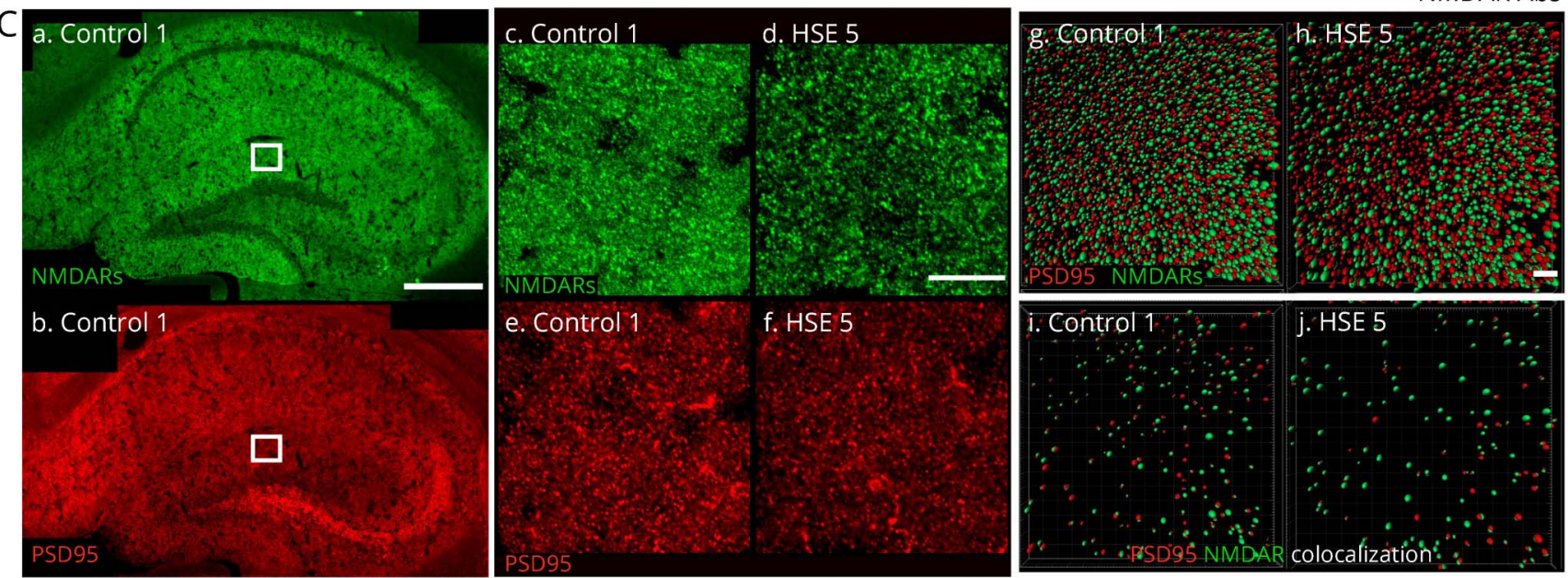

(A) Epifluorescence composites of hippocampi from mice inoculated with vehicle solution (control mice) 1 and 2 (b and a) and mice inoculated with HSV-1 (HSE) 1-6 (c-h) immunostained to assess the levels of membrane clusters of NMDARs. HSE mice 1 and 2 (c and d) did not develop serum antibodies (Abs) to NMDARs, HSE mice 3 and 4 (e and $f$ ) transiently made Abs at 6 and 3 weeks, and HSE mice 5 and 6 ( $g$ and $h$ ) had serum NMDAR Abs at the time of sacrifice ( 8 weeks). Boxes in $\mathrm{b}$ demonstrate sites that were further imaged under a confocal microscope for all mice. Scale bar $=500 \mu \mathrm{m}$. (B) Quantification of colocalized NMDAR and PSD95 clusters (= postsynaptic membrane NMDAR clusters) averaged from 3- $\mu \mathrm{m}$ stacks across the 15 hippocampal regions outlined in A.b for all groups (a) and then further grouped by serum NMDAR antibody status (b). Data are presented as mean \pm standard error of the mean (SEM). Significance of NMDAR Ab presence on postsynaptic NMDAR cluster number was assessed by one-way ANOVA for all groups and with Mann-Whitney $U$ test for pooled analysis; ${ }^{*} p<0.05$. (C) Epifluorescence composites of NMDAR staining (a) and PSD95 staining (b) for control mouse 1 (scale bar $=500 \mu \mathrm{m}$ ). Square represents an area that was further imaged on a confocal microscope (c-j). Representative confocal 2D images of NMDAR clusters (c and d) and PSD95 clusters (e and f) for control mouse 1 and HSE mouse 5 from the region outlined in a and b. Note the decrease in NMDAR cluster numbers, with relatively preserved PSD95 cluster numbers for HSE mouse 5 compared with control mouse 1 (scale bar $=10 \mu \mathrm{m}$ ). Representative NMDAR (green) and PSD95 (red) clusters for 3D Z-stacks from the region outlined in a and b for control mouse 1 (g) and HSE mouse 5 (h). Note the decrease in NMDAR (green) clusters in stack from HSE mouse 5 compared with control mouse 1. (i and j) Colocalized NMDAR and PSD95 clusters (= postsynaptic membrane NMDAR clusters) in the Z-stacks from $g$ and h for control mouse 1 and HSE mouse 5. Note the decrease in postsynaptic membrane NMDAR clusters in this region in HSE mouse 5 vs control mouse 1 (scale bar $=3 \mu \mathrm{m}$ ).

memory and behavioral deficits, their brains are bound by patient IgG, and they show a decreased density of postsynaptic membrane NMDARs, NMDAR-mediated currents, and synaptic plasticity. In the model described here, mice produce their own NMDAR antibodies after HSE, mirroring what has been observed in patients with autoimmune encephalitis post-HSE. Behavioral studies were not a focus of this proof of principle study. They are planned for future investigations.

A recent prospective study of patients with HSE showed that $27 \%$ developed autoimmune encephalitis within 3 months after the viral infection. ${ }^{5}$ In most cases, the disorder associated with novel synthesis of NMDAR antibodies, but a few patients had transient antibody synthesis without overt clinical manifestations, and patients often developed additional antibodies against yet unknown protein antigens. Transient antibody synthesis and an IgG to an unknown target were similarly noted in the current animal model, the significance of which is left for future studies to clarify. Of interest, the outcome of patients with autoimmune encephalitis post-HSE was substantially worse than that of patients with classic (not HSE triggered) autoimmune encephalitis.

The recent findings in the human disease ${ }^{5}$ raise important questions related to where and how the immune response is triggered and potential measures to prevent the subsequent 
A

$\begin{array}{lllllllllll}\text { NMDAR Abs }^{\mathrm{a}} & - & - & - & - & + & + & - & - & \bar{y} \\ \text { NMDAR Abs }^{\mathrm{b}} & - & - & - & - & - & - & + & +\end{array}$

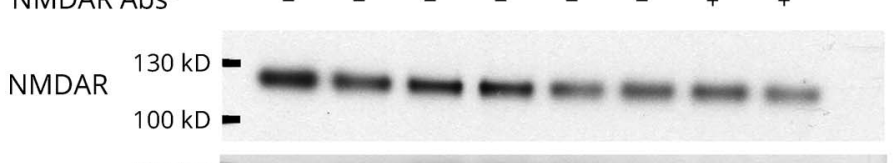

PSD95 $100 \mathrm{kD}=\mathrm{men}$

$50 \mathrm{kD}=$

Actin
Control

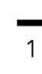

PoSt-HSE

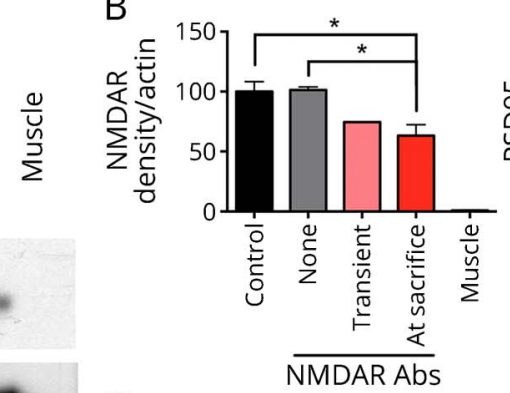

C

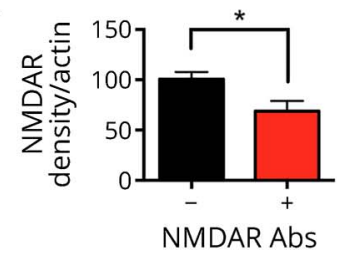

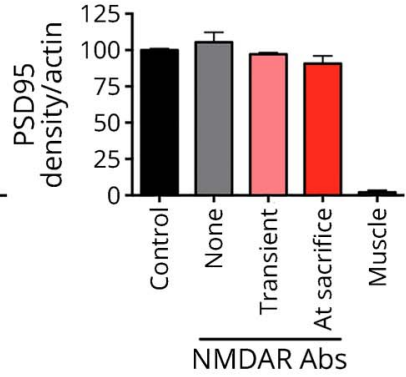

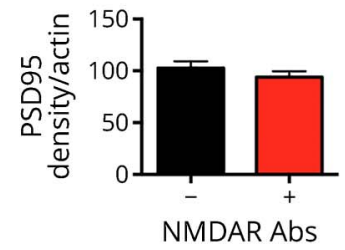

(A) Representative immunoblots of extranuclear proteins extracted from hippocampi of control mice and HSE mice, which were probed for NMDAR (GluN1 subunit), PSD-95, and actin (loading control). Muscle lysates were included as a control. Protein size is expressed as kilodaltons (kD). Note that there is less visible NMDAR protein in the hippocampi of mice that made antibodies (Abs) to NMDARs (mice 3-6), whereas the PSD-95 and actin protein amounts are similar in all the mice. Blots were run in duplicates. a NMDAR Abs transiently present. ${ }^{b}$ NMDAR Abs present at the time of sacrifice. (B) Quantification of hippocampal NMDAR and PSD-95 in control mice, HSE mice that never made NMDAR Abs, HSE mice that transiently made NMDAR Abs, and HSE mice that made NMDAR Abs at the time of sacrifice (8 weeks). (C) Quantification of hippocampal NMDAR and PSD-95 based on serum NMDAR antibody status. Results in B and C were normalized to actin (loading control), and mean band density of control mice was defined as $100 \%$. Data are presented as mean \pm SEM. Significance of serum NMDAR Ab presence on hippocampal NMDAR protein amount was assessed by one-way ANOVA (B) and Mann-Whitney $U$ test (C), respectively; ${ }^{*} p<0.05$.

autoimmune disorder. To answer these questions, we need an animal model, similar to that reported here, which will allow for investigations into the pathogenesis of this disorder, with the potential to provide insights that are generalizable to nonparainfectious autoimmune encephalitides, as they likely share common mechanisms and pathways. The task is now to determine in our model the behavioral impact of the NMDAR antibodies, what other antibodies are produced in this model, where and how the immune system is primed to produce neuronal antibodies in response to HSE, and to develop a treatment strategy, adjuvant to $\mathrm{ACV}$, that prevents neuronal antibody synthesis.

\section{Acknowledgment}

The authors thank Esther Aguilar, Dr. Ilona Linnoila, Dr. Anilkumar Nair, Dr. Daniel Wilton, and Dr. Anastasia Zekeridou for their technical assistance. Research reported in this publication was supported by the National Institute of Neurological Disorders and Stroke of the National Institutes of Health under the award numbers listed below. The content is solely the responsibility of the authors and does not necessarily represent the official views of the National Institutes of Health.

\section{Study funding}

This work was supported by the NIH/NINDS (R25 NS065743 [J.L.], K08 NS101084 [J.L.], R01 NS077851 [J.D.], R01 NS103998 [J.C.], and R01 NS070835 [J.C.]), Instituto Carlos III/FEDER 17/00234, CIBERER 15/00010, Fundació CELLEX (J.D.), Agència de Gestió d'Ajuts Universitaris i de Recerca (AGAUR; J.D.), CERCA Programme Generalitat de Catalunya (J.D.), Mutua Madrileña Foundation Award AP162572016
(T.A.), and the Radiologic Society of North America (Prince Research Grant; B.P.). The Microscopy Core facility of the Massachusetts General Hospital Program in Membrane Biology receives support from Boston Area Diabetes and Endocrinology Research Center grant DK57521 and Center for the Study of Inflammatory Bowel Disease grant DK43351. The Zeiss LSM 800 Airyscan confocal microscope was purchased using NIH Shared Instrumentation Grant 1S10OD021577-01.

\section{Disclosure}

J. Linnoila is an expert respondent for the National Vaccine Injury Compensation Program and received research support from the NIH/NINDS and Harvard Medical School/ Massachusetts General Hospital. B. Pulli received research support from the Radiologic Society of North America. T. Armangue received research support from the Mutua Madrilena Foundation. J. Planaguama, R. Narsimhan, and S. Schob report no disclosures. M. Zeller owns stock in Bayer. J. Dalmau is editor of Neurology: Neuroimmunology \& Neuroinflammation; is on the editorial board of Neurology UpToDate; receives royalties from $\mathrm{Ma} 2$ autoantibody test, NMDAR autoantibody test, GABA(B) receptor autoantibody test, GABA(A) receptor autoantibody test, DPPX autoantibody test, and IgLON5 autoantibody test; and received research support from the NIH, Instituto Carlos III/FEDER, Agència de Gestió d'Ajuts Universitaris i de Recerca, and CERCA Programme Generalitat de Catalunya-Fundació Cellex. J. Chen receives publishing royalties from Elsevier and research support from the NIH and National MS Society. Full disclosure form information provided by the authors is available with the full text of this article at Neurology.org/NN. 
Appendix 1 Author contribution

\begin{tabular}{|c|c|c|c|}
\hline Name & Location & Role & Contribution \\
\hline Jenny Linnoila, MD, PhD & $\begin{array}{l}\text { Massachusetts General } \\
\text { Hospital (MGH), Boston, MA }\end{array}$ & Author & $\begin{array}{l}\text { Study concept and design, acquisition of data, analysis and interpretation } \\
\text { of data, and writing of the manuscript }\end{array}$ \\
\hline Benjamin Pulli, MD & MGH, Boston & Author & $\begin{array}{l}\text { Study concept and design, implementation of experiments, analysis and } \\
\text { interpretation of data, and critical revision of the manuscript for } \\
\text { intellectual content }\end{array}$ \\
\hline Thaís Armangué, MD, PhD & $\begin{array}{l}\text { University of Barcelona, } \\
\text { Barcelona, Spain }\end{array}$ & Author & $\begin{array}{l}\text { Acquisition of data and critical review of the manuscript for } \\
\text { intellectual content }\end{array}$ \\
\hline Jesús Planagumà, PhD & $\begin{array}{l}\text { University of Barcelona, } \\
\text { Barcelona, Spain }\end{array}$ & Author & $\begin{array}{l}\text { Implementation of experiments and critical review of } \\
\text { the manuscript }\end{array}$ \\
\hline Radha Narsimhan, PhD & MGH, Boston & Author & Acquisition of data and critical review of the manuscript \\
\hline Stefan Schob, MD & $\begin{array}{l}\text { University Hospital, Leipzig, } \\
\text { Germany }\end{array}$ & Author & Study concept and design and critical review of the manuscript \\
\hline Matthias Zeller, MD & $\begin{array}{l}\text { Kepler University Hospital, } \\
\text { Linz, Austria }\end{array}$ & Author & Implementation of experiments and critical review of the manuscript \\
\hline Josep Dalmau, MD, PhD & $\begin{array}{l}\text { University of Barcelona, } \\
\text { Barcelona, Spain }\end{array}$ & Author & $\begin{array}{l}\text { Study concept and design, analysis and interpretation of data, critical } \\
\text { review of the manuscript for intellectual content, and study supervision }\end{array}$ \\
\hline John Chen, MD, PhD & MGH, Boston & Author & $\begin{array}{l}\text { Study concept and design, analysis and interpretation of data, critical } \\
\text { review of the manuscript for intellectual content, and study supervision }\end{array}$ \\
\hline
\end{tabular}

\section{Publication history}

Received by Neurology: Neuroimmunology \& Neuroinflammation September 4, 2018. Accepted in final form October 16, 2018.

\section{References}

1. Braun E, Zimmerman T, Hur TB, et al. Neurotropism of herpes simplex virus type 1 in brain organ cultures. J Gen Virol 2006;87(pt 10):2827-2837.

2. De Tiège $\mathrm{X}$, Rozenberg $\mathrm{F}$, Des Portes $\mathrm{V}$, et al. Herpes simplex encephalitis relapses in children: differentiation of two neurologic entities. Neurology 2003;61:241-243.

3. Prüss H, Finke C, Höltje M, et al. N-methyl-D-aspartate receptor antibodies in herpes simplex encephalitis. Ann Neurol 2012;72:902-911.

4. Armangue T, Leypoldt F, Málaga I, et al. Herpes simplex virus encephalitis is a trigger of brain autoimmunity. Ann Neurol 2014;75:317-323

5. Armangue T, Spatola M, Vlagea A, et al. Frequency, symptoms, risk factors, and outcomes of autoimmune encephalitis after herpes simplex encephalitis: a prospective observational study and retrospective analysis. Lancet Neurol 2018;17:760-772.

6. Brown SM, Ritchie DA, Subak-Sharpe JH. Genetic studies with herpes simplex virus type 1. The isolation of temperature-sensitive mutants, their arrangement into complementation groups and recombination analysis leading to a linkage map. J Gen Virol 1973;18:329-346.

7. Dalmau J, Gleichman AJ, Hughes EG, et al. Anti-NMDA-receptor encephalitis: case series and analysis of the effects of antibodies. Lancet Neurol 2008;7 1091-1098.

8. Planagumà J, Leypoldt F, Mannara F, et al. Human N-methyl D-aspartate receptor antibodies alter memory and behaviour in mice. Brain 2015;138:94-109.

9. Linnoila JJ, Binnicker MJ, Majed M, Klein CJ, McKeon A. CSF herpes virus and autoantibody profiles in the evaluation of encephalitis. Neurol Neuroimmunol Neuroinflamm 2016;3:e245. doi: 10.1212/NXI.0000000000000245.

10. Planagumà J, Haselmann $\mathrm{H}$, Mannara $\mathrm{F}$, et al. Ephrin-B2 prevents N-methyl-Daspartate receptor antibody effects on memory and neuroplasticity. Ann Neurol 2016; $80: 388-400$. 


\title{
Neurology \\ Neuroimmunology \& Neuroinflammation
}

\author{
Mouse model of anti-NMDA receptor post-herpes simplex encephalitis \\ Jenny Linnoila, Benjamin Pulli, Thaís Armangué, et al. \\ Neurol Neuroimmunol Neuroinflamm 2019;6; \\ DOI 10.1212/NXI.0000000000000529
}

This information is current as of December 26, 2018

\section{Updated Information \& Services}

References

Subspecialty Collections

Errata

Permissions \& Licensing

Reprints including high resolution figures, can be found at: http://nn.neurology.org/content/6/2/e529.full.html

This article cites 10 articles, 0 of which you can access for free at: http://nn.neurology.org/content/6/2/e529.full.html\#\#ref-list-1

This article, along with others on similar topics, appears in the following collection(s):

Autoimmune diseases

http://nn.neurology.org//cgi/collection/autoimmune_diseases

Encephalitis

http://nn.neurology.org//cgi/collection/encephalitis

Post-infectious

http://nn.neurology.org//cgi/collection/postinfectious_

An erratum has been published regarding this article. Please see next page or:

/content/6/3/e556.full.pdf

Information about reproducing this article in parts (figures,tables) or in its entirety can be found online at:

http://nn.neurology.org/misc/about.xhtml\#permissions

Information about ordering reprints can be found online: http://nn.neurology.org/misc/addir.xhtml\#reprintsus

Neurol Neuroimmunol Neuroinflamm is an official journal of the American Academy of Neurology.

Published since April 2014, it is an open-access, online-only, continuous publication journal. Copyright Copyright (C) 2018 The Author(s). Published by Wolters Kluwer Health, Inc. on behalf of the American Academy of Neurology.. All rights reserved. Online ISSN: 2332-7812.

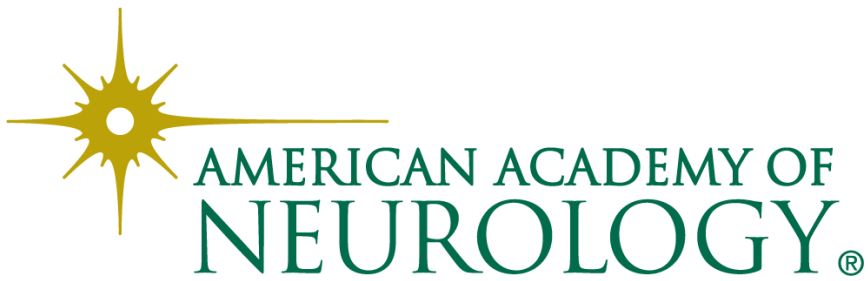




\section{CORRECTION}

\section{Mouse model of anti-NMDA receptor post-herpes simplex encephalitis}

Neurol Neuroimmunol Neuroinflamm 2019;6:e556. doi:10.1212/NXI.0000000000000556

In the article " Mouse model of anti-NMDA receptor post-herpes simplex encephalitis" by Linnoila et al., ${ }^{1}$ first published online December 26, 2018, there should have been a link included to access online supplemental materials: links.lww.com/NXI/A92. The publisher regrets the error.

\section{Reference}

1. Linnoila J, Pulli B, Armangué T, et al. Mouse model of anti-NMDA receptor post-herpes simplex encephalitis. Neurol Neuroimmunol Neuroinflamm 2019;6:e529. DOI: 10.1212/NXI.0000000000000529. 